\title{
Synthesis and properties of high tilted antiferroelectric esters with partially fluorinated alkoxyalkoxy terminal chains
}

\author{
M. ŻUROWSKA , R. DĄBROWSKI , J. DZIADUSZEK , K. CZUPRYŃSKI , K. SKRZYPEK , \\ M. FILIPOWICZ, N. BENNIS, and J.M. OTÓN \\ Institute of Chemistry, Military University of Technology, 2 Kaliskiego Str., 00-908 Warsaw, Poland \\ Universidad Politecnica de Madrid, ETSI Telecomunicacion, Ciudad Universitaria, 28040 Madrid, Spain
}

Novel chiral esters with partially fluorinated alkoxyalkoxy terminal chains are described. Their phase transition temperatures, enthalpies, and electrooptical properties are reported. A helical pitch in pure compounds and their mixtures based on selective reflection of light is also characterized.

Keywords: fluorinated esters, synthesis, phase transitions, helical pitch, electrooptical properties.

\section{Introduction}

For a few years we have been intensively searching the liquid crystal orthoconic antiferroelectrics because of their unusual optical properties ensuring a perfect dark state and consequently a very high contrast

Many homologous series of esters, mainly of formula I, with perfluoroalkanoyl unit in the terminal chain have been prepared
New, high tilted antiferroelectric broad range mixture W-232 with the longer pitch has been also formulated and characterized.

\section{Synthesis}

Esters synthesis was carried out by treating chiral phenol (C) with benzoic acid chloride see Scheme 1 .

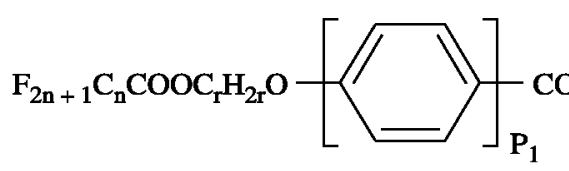

where $\mathrm{P}_{1}$ and $\mathrm{P}_{2}=1$ or 2 .

They have low melting point and low melting enthalpy which enable us to formulate orthoconic mixtures existing in a broad temperature range. Unfortunately, they have a very short helical pitch at a room temperature, so is possible to obtain a well unwounded helical structure only in very thin cells $(\sim 1 \mu \mathrm{m})$. We are looking for a liquid crystalline material with the longer pitch so, the compounds with partially fluorinated alkoxyalkoxy terminal chain are prepared.

The two homologous series of three-ring compounds expressed by general formula II

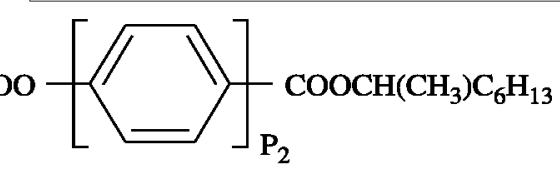

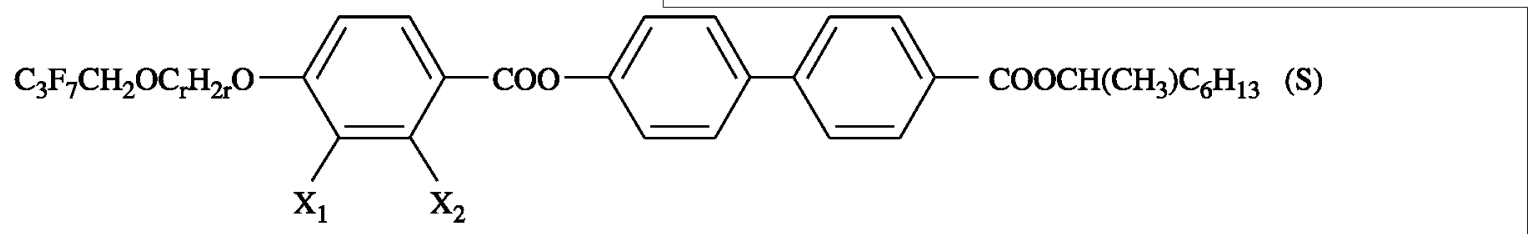

with $\mathrm{r}=5,6$, and $\mathrm{X}_{1}=\mathrm{H}, \mathrm{X}_{2}=\mathrm{F}$ or $\mathrm{X}_{1}=\mathrm{F}, \mathrm{X}_{2}=\mathrm{H}$ or $\mathrm{X}_{1}=$ $\mathrm{X}_{2}=\mathrm{H}$ or $\mathrm{X}_{1}=\mathrm{X}_{2}=\mathrm{F}$ are described here.
The efficient preparation of high optical purity phenol (C) was described recently in Ref. 5. The laterally substituted $\left(\mathrm{X}_{1}=\mathrm{H}, \mathrm{X}_{2}=\mathrm{F} ; \mathrm{X}_{1}=\mathrm{F}, \mathrm{X}_{2}=\mathrm{H}\right)$ and unsubstituted $\left(X_{1}=X_{2}=H\right)$ fluoroalkoxyalkoxy benzoic acids (A) were prepared according to Scheme 2.

For bilaterally substituted $\left(\mathrm{X}_{1}=\mathrm{X}_{2}=\mathrm{F}\right)$ fluoroalkoxyalkoxy benzoic acids (A1), the method shown in Scheme 3 was more convenient.

\section{Experiment}

All reagents were used for reactions as purchased ones, only toluene was dried by distillation over diphosphorus penta- 


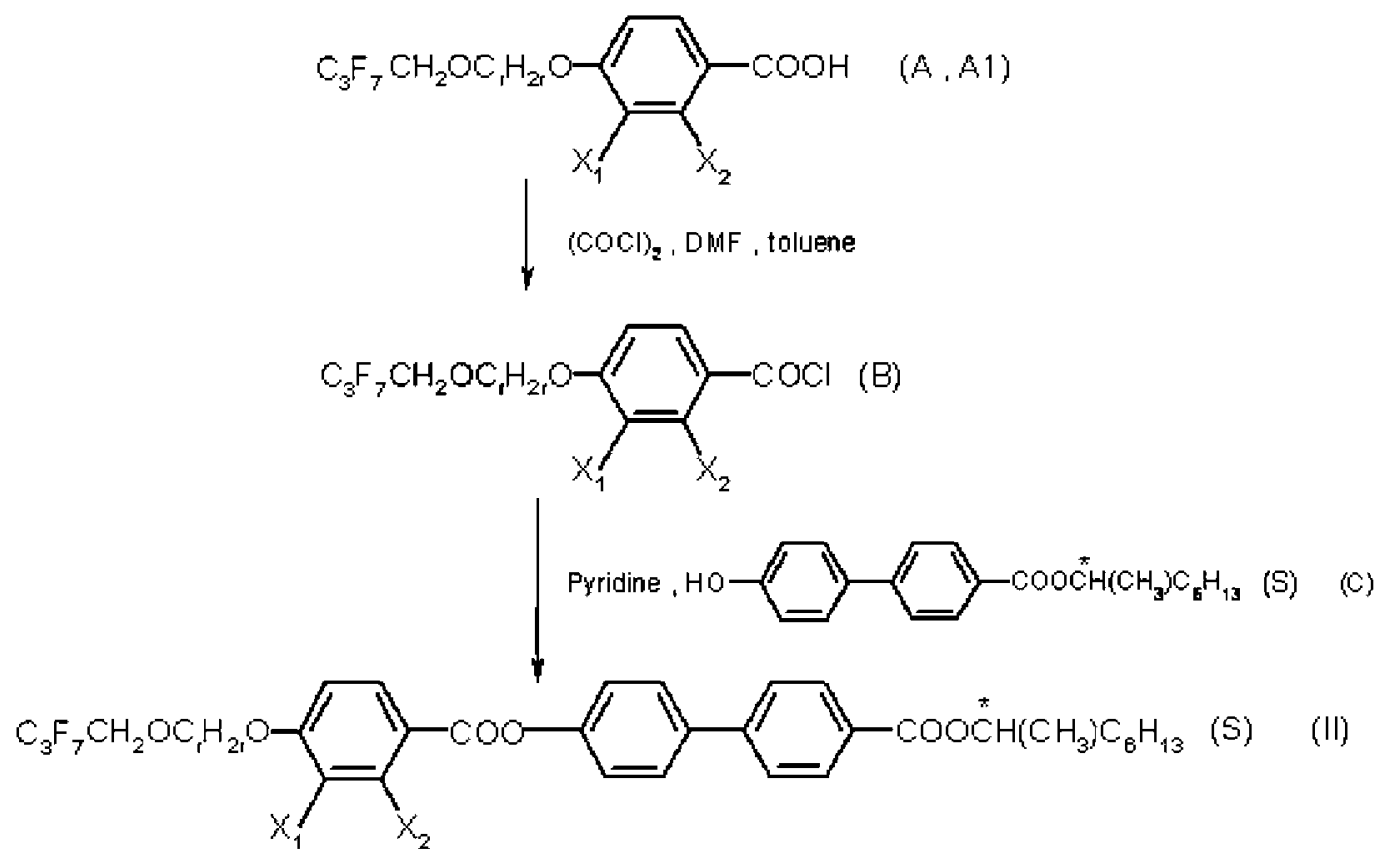

Scheme 1. Synthetic route of esters with a fluoroalkoxyalkoxy chain (II).

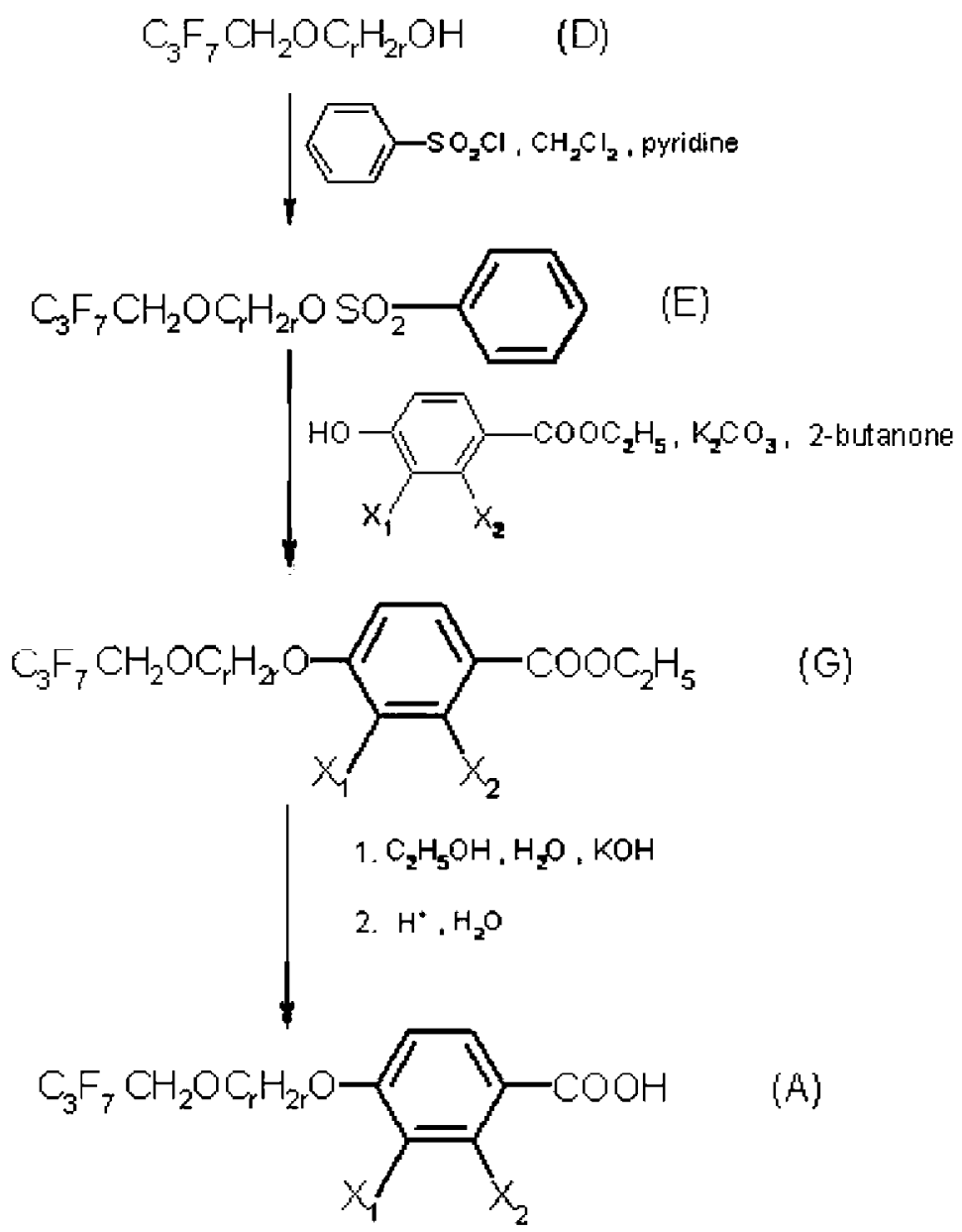

Scheme 2. Synthetic route of fluoroalkoxyalkoxy benzoic acids with $X_{1}=H, X_{2}=F ; X_{1}=F, X_{2}=H ; X_{1}=X_{2}=H(A)$. 


$$
\mathrm{C}_{3} \mathrm{~F}_{7} \mathrm{CH}_{2} \mathrm{OC}_{\mathrm{r}} \mathrm{H}_{2 \mathrm{r}} \mathrm{OH}
$$

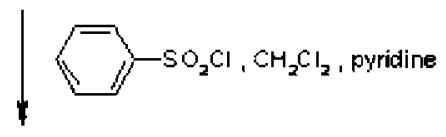

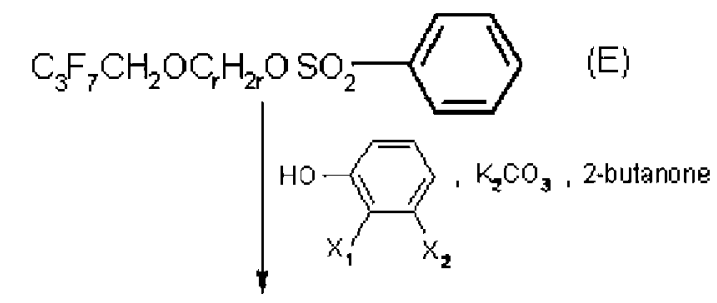<smiles>[X]c1cccc(OCCOCC(F)(F)F)c1[Y]</smiles><smiles>[Y]c1c(OCCOCC(F)(F)F)ccc(C(C)=O)c1[Y]</smiles><smiles>[X]c1c(OCCOCC(F)(F)F)ccc(C(=O)O)c1[Y]</smiles>

Scheme 3. Synthetic route of fluoroalkoxyalkoxy benzoic acids with $X_{1}=X_{2}=F(A 1)$. oxide. Purity (Table 1) and structure of the liquid crystalline esters (II) were confirmed using Schimadzu prominence chromatograph with HPLC MS (API-ESI) detector 2010EV, methanol was used as eluent. The purity of other compounds was checked using Hewlett-Packard HP-6890N chromatograph with MS detector HP5973N. Details of the synthesis will be described in another paper

The sequence of phases and phase transition temperatures of the liquid crystals were measured by texture observation in "Biolar" polarizing microscope ( $\mathrm{PZO})$ equipped with "Linkam" TMS-93 hot stage. The temperatures of phase transitions and enthalpies were recorded by DSC "Setaram" 141 microcalorimeter in heating and cooling cycles at the rate of two degrees per minute.

The helical pitch in the pure compounds and their mixtures was calculated from the maximum of selective reflection of the light. For setting the maximum of selective reflection, the measurements of light transmission during a cooling cycle on Varian Cary 3 Ultraviolet-visible spectrophotometer in the range of $400-900 \mathrm{~nm}$ were made. Peltier elements were used for changing the temperature and the measurement temperature range was $5-100^{\circ} \mathrm{C}$. The temperature was fixed with the accuracy of $0.1^{\circ} \mathrm{C}$.

The well known dependence $\lambda_{\max }=n \cdot p$ connects the length of the selectively reflected light $\lambda_{\max }$ with the helical pitch $p$ of the compounds, where $n$ is the average refractive index. For the tested chiral compounds, the average refractive index is about 1.5 , thus the helical pitch can be calculated using the following relation $p \approx \lambda_{\max } / 1.5$

\section{Mesomorphic properties}

In Table 1, the phase transition temperatures and enthalpies are given for DSC measurements in heating cycle.

Table 1. Phase transition temperatures $\left({ }^{\circ} \mathrm{C}\right)$, enthalpies $\left(\mathrm{kJ} \cdot \mathrm{mol}^{-1}\right)$ and chromatographic purity of esters $1-8$.

\begin{tabular}{|c|c|c|c|c|c|c|c|c|c|c|c|c|c|}
\hline No & $\mathrm{r}$ & $X_{1}$ & $\mathrm{X}_{2}$ & $\mathrm{Cr}$ & & $\mathrm{SmC}_{\text {Anti }}{ }^{*}$ & & $\mathrm{SmC}^{*}$ & & $\mathrm{SmA}$ & & Iso & $\begin{array}{c}\text { Chromatographic } \\
\text { purity }(\%)\end{array}$ \\
\hline 1 & 6 & $\mathrm{H}$ & F & $*$ & $\begin{array}{l}42.2 \\
34.2\end{array}$ & $*$ & $\begin{array}{c}73.9 \\
0.038\end{array}$ & $*$ & $\begin{array}{c}103.7 \\
4.6\end{array}$ & $*$ & $\begin{array}{c}(108.5) \\
2.1\end{array}$ & $*$ & 98.9 \\
\hline 2 & 6 & $\mathrm{~F}$ & $\mathrm{H}$ & $*$ & $\begin{array}{l}57.3 \\
24.3\end{array}$ & $*$ & $\begin{array}{c}80.1 \\
0.017\end{array}$ & $*$ & $\begin{array}{l}108.5 \\
1.15\end{array}$ & $*$ & $\begin{array}{c}112.7 \\
4.4\end{array}$ & $*$ & 99.4 \\
\hline 3 & 6 & $\mathrm{~F}$ & $\mathrm{~F}$ & $*$ & $\begin{array}{l}62.6 \\
23.2\end{array}$ & $*$ & $\begin{array}{c}84.8 \\
0.013\end{array}$ & $*$ & $\begin{array}{c}110.5 \\
0.8\end{array}$ & $*$ & $\begin{array}{c}112.8 \\
3.9\end{array}$ & $*$ & 98.6 \\
\hline 4 & 6 & $\mathrm{H}$ & $\mathrm{H}$ & $*$ & $\begin{array}{l}60.5 \\
24.0\end{array}$ & $*$ & $\begin{array}{c}94.7 \\
0.025\end{array}$ & $*$ & $\begin{array}{c}124.8 \\
1.47\end{array}$ & $*$ & $\begin{array}{c}126.3 \\
4.1\end{array}$ & $*$ & 99.9 \\
\hline 5 & 5 & $\mathrm{H}$ & $\mathrm{F}$ & $*$ & $\begin{array}{l}28.1 \\
34.9\end{array}$ & $*$ & $\begin{array}{c}(97.0) \\
0.1\end{array}$ & $*$ & - & $*$ & $\begin{array}{c}99.0 \\
5.4\end{array}$ & $*$ & 99.9 \\
\hline 6 & 5 & $F$ & $\mathrm{H}$ & $*$ & $\begin{array}{l}68.7 \\
25.4\end{array}$ & $*$ & $108.8^{*}$ & $*$ & $\begin{array}{c}106.8 \\
1.4\end{array}$ & * & $\begin{array}{c}109.6 \\
3.7\end{array}$ & $*$ & 99.4 \\
\hline 7 & 5 & $\mathrm{H}$ & $\mathrm{H}$ & $*$ & $\begin{array}{l}66.8 \\
18.0\end{array}$ & $*$ & $\begin{array}{l}121.0 \\
0.09\end{array}$ & $*$ & $\begin{array}{c}123.3 \\
5.8\end{array}$ & $*$ & - & $*$ & 99.7 \\
\hline 8 & 5 & $F$ & $\mathrm{~F}$ & * & $\begin{array}{l}53.5 \\
21.6\end{array}$ & $*$ & $\begin{array}{c}(106.7) \\
0.038\end{array}$ & $*$ & $\begin{array}{c}107.7 \\
1.1\end{array}$ & * & $\begin{array}{c}109.2 \\
3.9\end{array}$ & $*$ & 98.1 \\
\hline
\end{tabular}

Upper row - temperatures, lower row - enthalpies, ( ) - temperatures obtained during a cooling cycle, * - temperatures from a polarizing microscope. 
All compounds have anticlinic smectic phase $\left(\mathrm{SmC}_{\text {Anti }}{ }^{*}\right)$ in a broad temperature range and synclinic smectic phase $\left(\mathrm{SmC}^{*}\right)$ and orthogonal smectic phase $(\mathrm{SmA})$ above it in a narrow temperature range. The temperature range of $\mathrm{SmC}^{*}$ and $\operatorname{SmA}$ phases is narrower in series $r=5$ than in series $r=6$. For compound 7 , the SmA phase disappears totally.

\section{Helical pitch}

The results concerning the helical pitch are listed below in Table 2 .

Table 2. Helical pitch length of $1-5 \mathrm{~nm}$ in pure compounds.

\begin{tabular}{cc}
\hline Compounds & Estimated pitch at $20^{\circ} \mathrm{C}$ \\
\hline 1 & 502 \\
2 & - \\
3 & 1091 \\
4 & 1078 \\
5 & 1471 \\
\hline
\end{tabular}

All compounds show selective reflection in the visible range (about $500-600 \mathrm{~nm}$ ) in the ferroelectric phase but in the antiferroelectric phase only compound 1 reflects the light in the visible range (about 700-900 nm) at the temperatures higher than $20^{\circ} \mathrm{C}$, Figs. 1 and 2 .

To estimate the pitch of other compounds $2-8$, the selective reflection of their $10 \mathrm{~mol} \%$ mixtures in 1 were investigated. For the mixtures of 1 with compound 3 or 4 or 5 , the maximum selectively reflected light is shifted to an infrared region and for the mixtures of 1 with compounds $2,6,7$, and 8 , the absorption is outside the spectrophotometer operating range. Thus, the values of a helical pitch

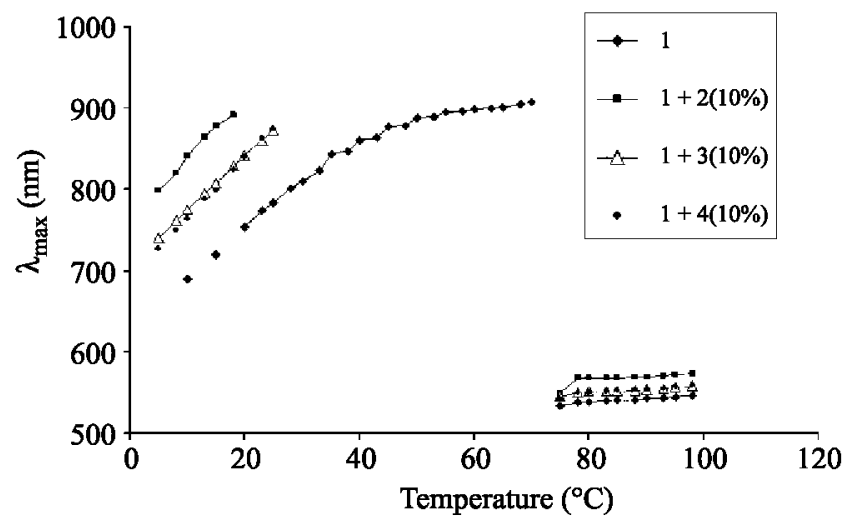

Fig. 1. Temperature dependence of maximum selective reflection in bicomponent mixtures of compound 1 with 2 or 3 or 4 .

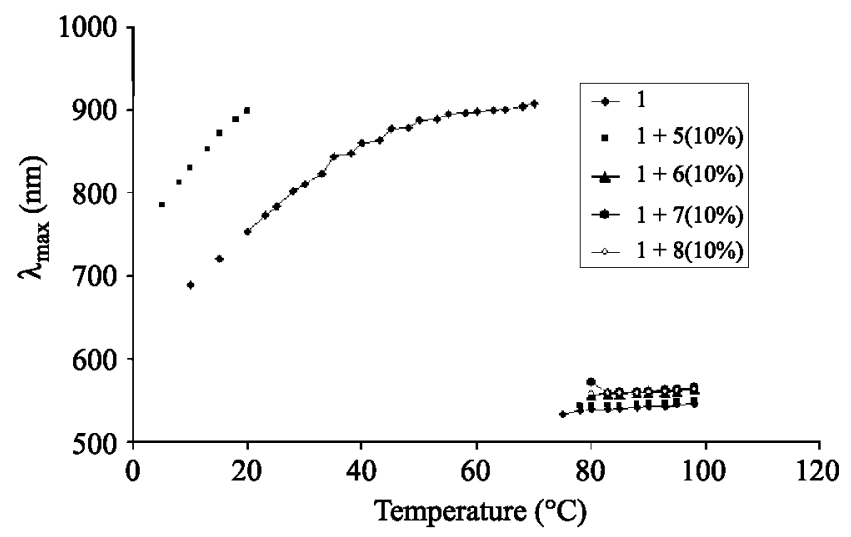

Fig. 2. Temperature dependence of maximum selective reflection in bicomponent mixtures of compound 1 with 5 or 6 or 7 or 8 .

for pure compounds are between 500-1500 nm (Table 2) or even higher.

Table 3. Components of the mixture W-232.
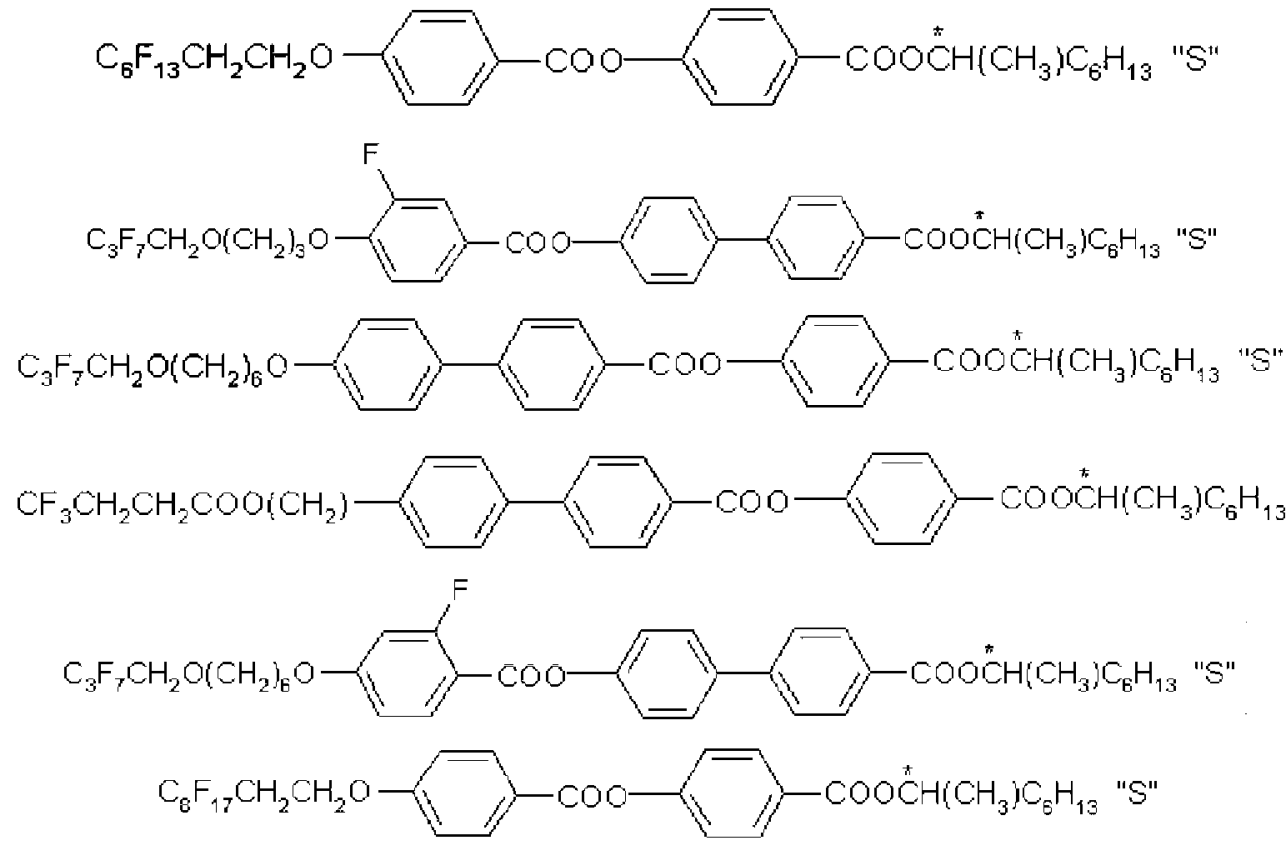


\section{Electrooptical properties}

The multicomponent eutectic mixture W-232 composed of six compounds (Table 3 ) was formulated and electrooptical properties were characterized (Table 4). Manufacturing processes of the cell test have been performed in a clean room environment. The 1.6-um cell gap is controlled by the spacers inside the cell and in the sealing adhesive (gasket). Nylon- 6 as orienting polymer $\left(6.7 \mathrm{gdm}^{-3}\right)$ has been spin coated on both electrodes and then cured and rubbed in the same direction, finally the cell was filled with the mixture $\mathrm{W}-232$.

Table 4. Phase transition temperatures from a polarizing microscope and electrooptical properties of the mixture W-232 (at $35^{\circ} \mathrm{C}$ ).

\begin{tabular}{lc}
\hline \multicolumn{2}{c}{ Mixture $\mathrm{W}-232$} \\
\hline Melting point $\left({ }^{\circ} \mathrm{C}\right)$ & 7.64 \\
Clearing point $\left({ }^{\circ} \mathrm{C}\right)$ & 99.89 \\
SmC $_{\text {Anti }}{ }^{*}-\mathrm{SmC} *\left({ }^{\circ} \mathrm{C}\right)$ & $68.0-68.9$ \\
SmC $^{*}-\mathrm{SmA}\left({ }^{\circ} \mathrm{C}\right)$ & $76.5-78.2$ \\
SmA-Iso $\left({ }^{\circ} \mathrm{C}\right)$ & $88.6-95.5$ \\
Tilt angle, $\theta\left({ }^{\circ}\right)$ & 40 \\
Spontaneous polarization, $\mathrm{P}_{\mathrm{s}}\left(\mathrm{nC} \mathrm{cm}^{-2}\right)$ & 230 \\
Threshold voltage, $V_{t h}(\mathrm{~V})$ & 9.5 \\
Saturation voltage, $V_{s a t}(\mathrm{~V})$ & 12 \\
Response time: & 70 \\
Rise, $t_{r}(\mu \mathrm{s})$ & 400 \\
Fall, $t_{f}$ ( $\left.\mathrm{us}\right)$ & \\
\hline
\end{tabular}

Temperatures obtained during heating cycle.

The electrooptical parameters were measured at $35^{\circ} \mathrm{C}$. A standard characterisation protocol consisting of low frequency hysteresis curve (Fig. 3) and grey level generation (Fig. 4) was obtained when the cell is derived with a driving scheme given in Ref. 8.

The mixture W-232 with an optical tilt saturates at 40 degree (at $35^{\circ} \mathrm{C}$ ) and shows better electrooptical performance than the fully orthoconic mixture W-193B exhibiting a very short pitch with often avoided correct align-

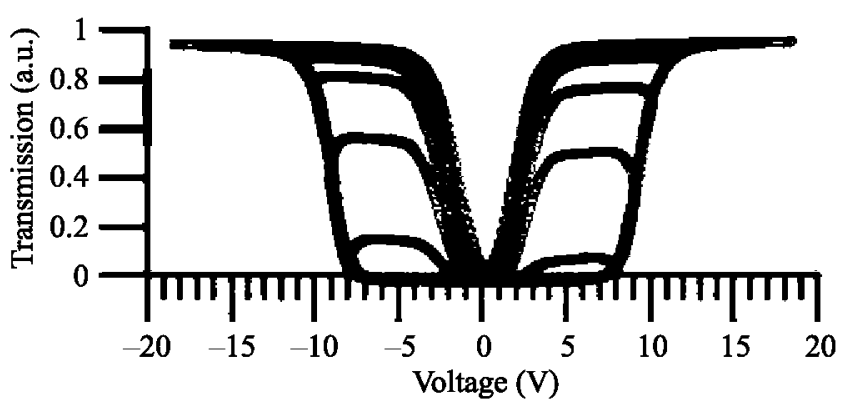

Fig. 3. Hysteresis loop at $0.1 \mathrm{~Hz}$ for the mixture W-232.

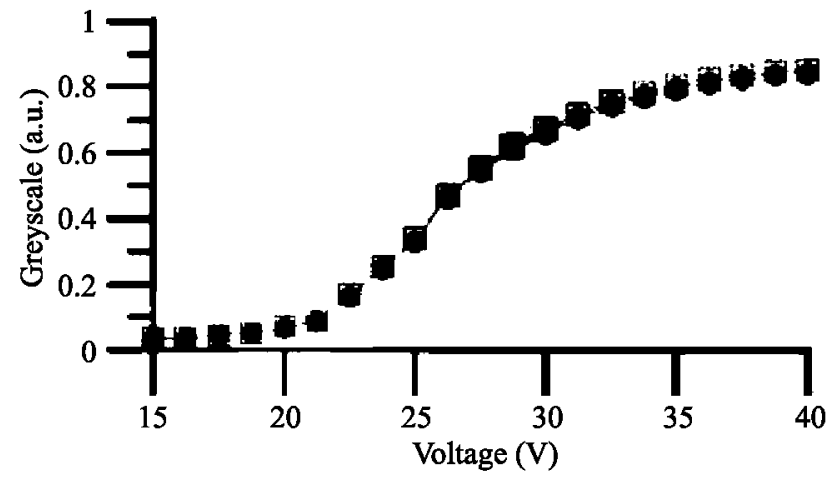

Fig. 4. Greyscale in dynamic conditions for the mixture W-232.

ment, resulting in asymmetry in an electrooptical response and shows unsatisfactory dynamic behaviour and exceedingly high voltage levels. However, the electrooptical properties, measured in a cell filled with W-232, exhibiting long pitch and high spontaneous polarization $\left(\mathrm{Ps}=230 \mathrm{nCcm}^{-2}\right)$, show lower threshold and saturation voltage, fully symmetric hysteresis curve and more linear greyscale. Consequently, these materials could be used for display application.

\section{Conclusions}

The compounds with partially fluorinated alkoxyalkoxy terminal chain have antiferroelectric phase in a broad temperature range similar to the compounds with partially fluorinated alkanoyloxyalkoxy chain. Their pitch is longer than $1000 \mathrm{~nm}$ for unsubstituted compounds $(4,7)$ or monosubstituted by fluorine atom in position 2 to the carboxylic group compounds $(2,6)$.

The mixture W-232 with the longer pitch shows the same hysteresis curves for positive and negative pulses, but response times are still strongly asymmetric.

\section{Acknowledgements}

The work was carried under the Polish Ministry of Science and Higher Education PBW 982 project.

\section{References}

S. Lagerwall, A. Dahlgren, P. Jagemal, P. Rudquist, K. D'have, H. Pauwels, R. Dą̧browski, and W. Drzewiński, "Unique electro-optical properties of liquid crystals designed for molecular optics", Adv. Funct. Mater. 11, 87-94 (2001).

R. Dạbrowski, J. Gąsowska, J.M. Otón, W. Piecek, J. Przedmojski, and M. Tykarska, "High tilted antiferroelectric liquid crystalline materials", Displays 25, 9-19 (2004). J. Gąsowska, R. Dąbrowski, W. Drzewiński, M. Filipowicz, J. Przedmojski, and K. Kenig, "Comparison of mesomorphic properties in chiral and achiral homologous series of high tilted ferroelectrics and antiferroelectrics", Ferroelectrics 309, 83-93 (2004). 
E. Sokót, W. Drzewiński, J. Dziaduszek, R. Dąbrowski, N. Bennis, and J.M. Otón, "The synthesis and properties of novel partially fluorinated ethers with high tilted anticlinic phase", Ferooelectrics 343, 41-48 (2006).

W. Drzewiński, R. Dąbrowski, and K. Czupryński, "Orthoconic antiferroelectrics. Synthesis and mesomorphic properties of optically active (S)-(+)-4-(1-methylheptyloxycarbonyl)phenyl 4'-(fluoroalkanoyloxyalkoxy)biphenyl-4-carboxylates and 4'-(alkanoyloxyalkoxy)biphenyl-4-carboxylates", Pol. J. Chem. 76, 273-284 (2002).
M. Żurowska, R. Dąbrowski, and J. Dziaduszek, "Synthesis and mesomorphic properties of novel antiferroelectric esters with partially fluorinated alkoxyalkoxy terminal chains", Liq. Cryst. (to be published)

Z. Raszewski, J. Kędzierski, P. Perkowski, W. Piecek, J. Rutkowska, S. Kłosowicz, and J. Zieliński, "Refractive indices of the MHPB(H)PBC and MHPB(F)PBC antiferroelectric liquid crystals", Ferroelectrics 276, 289-300 (2002). A. Spadło, N. Bennis, R. Dąbrowski, X. Quintana, J.M. Otón, and M.A. Geday, "Modifying electrooptics of orthoconic antiferroelectric liquid crystal cells by manufacturing procedures", Opto-Electron. Rev. 15, 60-65 (2007). 